\title{
Optimization of Cutting Parameters in Hard Turning of OHNS Steel
}

\author{
Anil Raj, K. Leo Dev Wins, M. Dev Anand
}

\begin{abstract}
Turning of hardened steel is normally carried out with copious supply of cutting fluid to improve the cutting performance. Most of the cutting fluids in regular use are petroleum based emulsions which create several environmental problems. In this context, pure dry machining is a logical alternative as it is free from the problems associated with the cutting fluid. In this study an effort was made to study the effect of flank wear and cutting temperature during hard turning of OHNS steel under dry condition. A detailed analysis was performed using Taguchi technique to find out the effect of above mentioned parameters. Analysis of Variance (ANOVA) was carried out to find out the influence of individual parameters on flank wear and cutting temperature. Confirmation tests were performed to compare the predicted values with the experimental values and it was found that the results matched well with the experimental results.
\end{abstract}

Keywords--- Hard Turning, OHNS, Dry Turning.

\section{INTRODUCTION}

Turning of hardened steel involves application of large quantities of cutting fluid. Procurement, storage and disposal of cutting fluid involve expenses and large scale use of cutting fluid causes serious environmental and health hazards on the shop floor. It may also foul up the machine tool and disposal of cutting fluid has to comply with environmental legislations as well. In this situation, pure dry machining is a logical alternative which is totally free from the problems associated with storage and disposal of cutting fluid [1 and 2].

Less work has been reported in the area of dry machining, especially in the area of hard turning [3-5]. The present work aims at a systematic investigation of flank wear and cutting temperature during dry turning of OHNS steel of hardness 43 HRC. The scheme is environmental friendly and free from the problems associated with the cutting fluid. The input parameters taken for this experiment are cutting speed, feed and depth of cut. Likewise, the output parameters taken for this particular experiment are flank wear and cutting temperature.

\section{EXPERIMENT}

\subsection{Selection of Work Piece}

OHNS (Oil Hardened Non Shrinkable) Steel of hardness $43 \mathrm{HRC}$ with $375 \mathrm{~mm}$ length and $70 \mathrm{~mm}$ diameter was selected as a work material for this investigation which is widely used in die making, casting and allied industries. It is known for its toughness, fatigue strength and tensile

Revised Manuscript Received on July 10, 2019

Anil Raj, Department of Manufacturing Engineering, Karunya University, Coimbatore, Tamil Nadu, India. (e-mail: anilpidaram@yahoo.com)

K. Leo Dev Wins, Department of Manufacturing Engineering, Karunya University, Coimbatore, Tamil Nadu, India.

M. Dev Anand, Professor and Director Research, Department of Mechanical Engineering, Noorul Islam Centre for Higher Education, Kumaracoil, Tamil Nadu, India. strength. The composition of OHNS steel is shown in Table 1.

Table 1: Composition of Work Piece Material
\begin{tabular}{|c|c|c|c|c|c|c|}
\hline C & Mn & Cr & W & V & Si & Fe \\
\hline 0.95 & 1.15 & 0.5 & 0.5 & 0.2 & 0.28 & balance \\
\hline
\end{tabular}

\subsection{Selection of Cutting Tool and Tool Holder}

The cutting tool inserts and the tool holder were selected as per the recommendations of $\mathrm{M} / \mathrm{s}$ TaeguTec India (P) Limited who extend their technical/material support for this research work. Accordingly, multicoated hard metal inserts with sculptured rake face with a specification SNMG 120408and tool holder with the specification PSBNR 2525 were used in the investigation.

Figure 1 shows the experimental set up which consists of a medium duty Kirloskar lathe which was modified with DC motors to provide variable speed and feed using variable controllers. Table 2 shows the three input parameters and their levels.

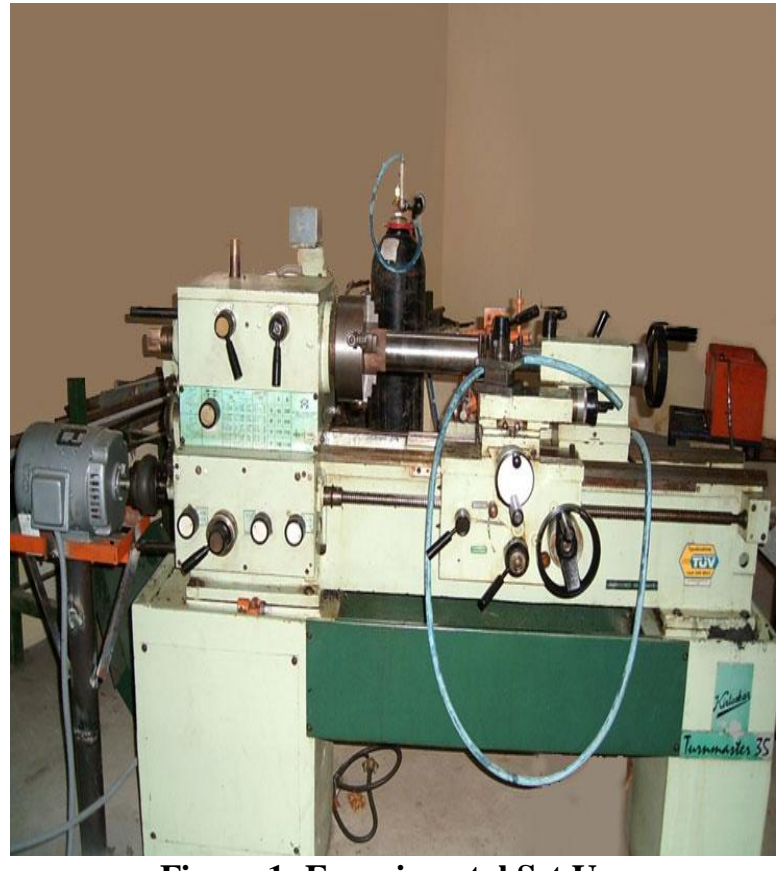

Figure 1: Experimental Set Up

Table 2: Input Parameters and Their Levels

\begin{tabular}{|l|l|}
\hline Cutting Speed v(m/min $)$ & $75,95,115$ \\
\hline Feed Rate $\mathrm{f}(\mathrm{mm} / \mathrm{rev})$ & $0.05,0.075,0.1$ \\
\hline Depth of Cut $\mathrm{d}(\mathrm{mm})$ & $0.5,0.75,1$ \\
\hline
\end{tabular}

\section{Design of Experiment}

A 9 run experiment was designed based on TaguchiLg orthogonal array [6] is shown in the Table 3. 
Table 3: Design Matrix for Nine-Run, Three-Level Experiment with Three Factors

\begin{tabular}{|c|c|c|c|}
\hline Standard Order & \multicolumn{3}{|c|}{$\begin{array}{c}\text { Factor } \\
\text { Columns }\end{array}$} \\
\hline 1 & 1 & 1 & 1 \\
\hline 2 & 1 & 2 & 2 \\
\hline 3 & 1 & 3 & 3 \\
\hline 4 & 2 & 1 & 2 \\
\hline 5 & 2 & 2 & 3 \\
\hline 6 & 2 & 3 & 1 \\
\hline 7 & 3 & 1 & 3 \\
\hline 8 & 3 & 2 & 1 \\
\hline 9 & 3 & 3 & 2 \\
\hline
\end{tabular}

In the experimental phase, preliminary experiments were conducted through trial runs. Trial runs helped in fixing the range of parameters. In the second phase, experiments were carried out using Taguchi $\mathrm{L}_{9}$ orthogonal array with

Table 4: Experimental Data Collected During 9 Run Experiment

\begin{tabular}{|l|l|l|l|l|l|}
\hline $\begin{array}{l}\text { Sl. } \\
\text { N } \\
\text { o. }\end{array}$ & $\begin{array}{l}\text { Cutting } \\
\text { Speed } \\
(\mathbf{m} / \mathbf{m i n})\end{array}$ & $\begin{array}{l}\text { Feed } \\
\text { Rate } \\
(\mathbf{m m} / \mathbf{r e} \\
\mathbf{v})\end{array}$ & $\begin{array}{l}\text { Depth } \\
\text { of Cut } \\
(\mathbf{m m})\end{array}$ & $\begin{array}{l}\text { Tempe } \\
\text { rature } \\
\left({ }^{\circ} \mathbf{C}\right)\end{array}$ & $\begin{array}{l}\text { Flank } \\
\text { Wear } \\
(\mathbf{m m})\end{array}$ \\
\hline 1. & 75 & 0.05 & 0.5 & 150.5 & 0.051 \\
\hline 2. & 75 & 0.075 & 0.75 & 156.5 & 0.056 \\
\hline 3. & 75 & 0.1 & 1 & 178 & 0.069 \\
\hline 4. & 95 & 0.05 & 0.75 & 151.5 & 0.054 \\
\hline 5. & 95 & 0.075 & 1 & 149.5 & 0.036 \\
\hline 6. & 95 & 0.1 & 0.5 & 112 & 0.028 \\
\hline 7. & 115 & 0.05 & 1 & 202.3 & 0.079 \\
\hline 8. & 115 & 0.075 & 0.5 & 120 & 0.027 \\
\hline 9. & 115 & 0.1 & 0.75 & 151 & 0.056 \\
\hline
\end{tabular}

\section{RESULTS AND DISCUSSION}

Figure 2 presents the relative significance of the cutting parameters on cutting temperature.

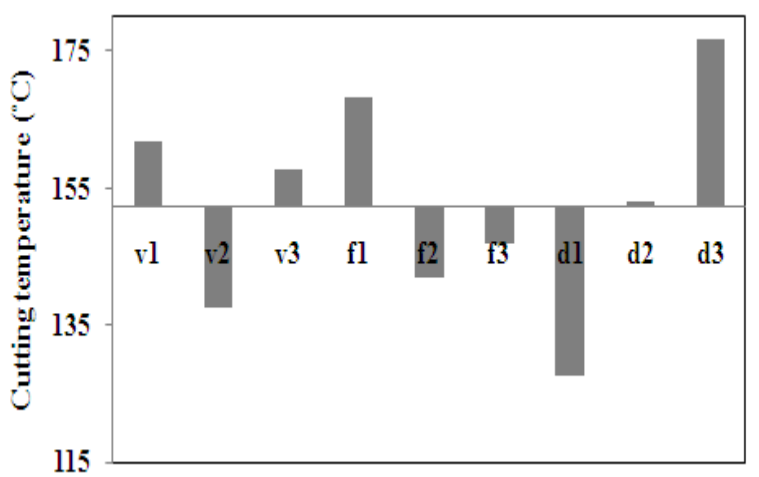

Figure 2: Relative Significance of Dry Machining on Attainable Temperature

(v - Cutting Speed, f - Feed Rate d - Depth of Cut)

ANOVA analysis was also carried out using Qualitek-4 software to find out the percentage influence of individual parameters on cutting temperature and flank wear. It was found that the interaction effects were not significant. experimental values and are presented in Table 4.

Table 5sum up the results of ANOVA analysis of the data on cutting temperature to identify the level of significance of cutting parameters.

Table 5: ANOVA Summary of the Input Parameters on Temperature

\begin{tabular}{|l|c|c|c|c|c|c|}
\hline $\begin{array}{l}\text { Col\#/ } \\
\text { Factor }\end{array}$ & $\begin{array}{c}\text { DO } \\
\text { F }\end{array}$ & $\begin{array}{c}\text { Sum Of } \\
\text { Sqrs. } \\
(\mathrm{S})\end{array}$ & $\begin{array}{c}\text { Variance } \\
\text { V) }\end{array}$ & $\begin{array}{c}\text { F- } \\
\text { Ratio } \\
(\mathrm{F})\end{array}$ & $\begin{array}{c}\text { Pure } \\
\text { Sum(S') }\end{array}$ & $\begin{array}{c}\text { Percent( } \\
\%)\end{array}$ \\
\hline $\begin{array}{l}\text { Cutting } \\
\text { Speed } \\
(\mathrm{m} / \mathrm{min})\end{array}$ & 2 & 995.224 & 497.612 & 10.56 & 900.987 & 15.378 \\
\hline $\begin{array}{l}\text { Feed } \\
\text { Rate } \\
(\mathrm{mm} / \mathrm{re} \\
\text { v) }\end{array}$ & 2 & $\begin{array}{c}1151.40 \\
9\end{array}$ & 575.704 & $\begin{array}{c}12.21 \\
8\end{array}$ & $\begin{array}{c}1057.17 \\
3\end{array}$ & 18.043 \\
\hline $\begin{array}{l}\text { Depth } \\
\text { of Cut } \\
(\mathrm{mm})\end{array}$ & 2 & $\begin{array}{l}3618.00 \\
9\end{array}$ & 1809.004 & $\begin{array}{c}38.39 \\
2\end{array}$ & 2523.77 & 60.144 \\
\hline Error & 2 & 94.236 & 47.118 & - & - & 6.435 \\
\hline Total & 8 & 5858.88 & & & & $100.00 \%$ \\
\hline
\end{tabular}

From the ANOVA results, it was evident that depth of cut forms the most significant parameter influencing the cutting temperature(60.144\%).From Figure 2, it is seen that cutting speed at level - $2(95 \mathrm{~m} / \mathrm{min})$, feed rate at level - 2 $(0.075 \mathrm{~mm} / \mathrm{rev})$, depth of cut at level $-1(0.5 \mathrm{~mm})$ contributed more on the reduction of cutting temperature.

Figure 3 presents the relative significance of cutting parameters on flank wear and Table 6 sum up the results of ANOVA analysis of the data on flank wear to identify the level of significance of cutting parameters.

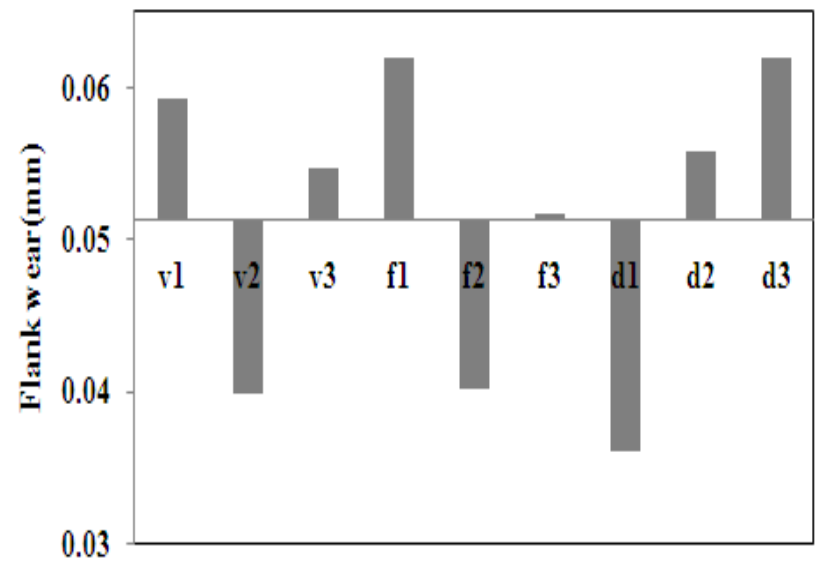

Figure 3: Relative Significance of Dry Machining Parameters on Flank wear

( $v$ - Cutting Speed,f -Feed Rate, d - Depth of cut)

From Figure 3 the cutting speed at level - $2(95 \mathrm{~m} / \mathrm{min})$, feed rate at level $-2(0.075 \mathrm{~mm} / \mathrm{rev})$, depth of cut at level -1 $(0.5 \mathrm{~mm})$, contributed more on the reduction of flank wear.

Published By: Blue Eyes Intelligence Engineering 
Table 6: ANOVA summary of the input parameters on flank wear

\begin{tabular}{|l|c|c|c|c|c|c|}
\hline \multicolumn{1}{|c|}{ Col\#/ } & $\begin{array}{c}\text { DO } \\
\text { Factor } \\
\text { F } \\
\text { (f) }\end{array}$ & $\begin{array}{c}\text { Sum } \\
\text { of } \\
\text { Squar } \\
\text { es. (S) }\end{array}$ & $\begin{array}{c}\text { Varian } \\
\text { ce (V) }\end{array}$ & $\begin{array}{c}\text { F- } \\
\text { Rati } \\
\text { o (F) }\end{array}$ & $\begin{array}{c}\text { Pur } \\
\text { e } \\
\text { Su } \\
\text { m } \\
\left(S^{\prime}\right)\end{array}$ & $\begin{array}{c}\text { Percen } \\
\text { t (\%) }\end{array}$ \\
\hline $\begin{array}{l}\text { Cutting } \\
\text { speed(m/ } \\
\text { min) }\end{array}$ & 2 & 0 & 0 & 6.10 & 0 & 20.205 \\
\hline $\begin{array}{l}\text { Feed } \\
\text { rate(mm/r } \\
\text { ev) }\end{array}$ & 2 & 0 & 0 & $\begin{array}{c}7.04 \\
6\end{array}$ & 0 & 23.925 \\
\hline $\begin{array}{l}\text { Depth of } \\
\text { cut(mm) }\end{array}$ & 2 & 0.001 & 0 & 11.1 & 0.0 & 40.042 \\
\hline Error & 2 & -0.001 & -0.001 & - & - & 15.828 \\
\hline Total & 8 & 0.002 & - & - & - & 100.00 \\
$\%$
\end{tabular}

From the ANOVA results, it is evident that depth of cut forms the most significant parameter influencing the flank wear. The percentage significance of depth of cut on flank wear was $40.042 \%$.

The results of the analysis which lead to a set of levels of cutting parameters to minimize cutting temperature and flank wear are summarized in Table 7.

Table 7: Summary of Cutting Parameters for Optimum performance

\begin{tabular}{|c|c|c|c|c|c|c|c|c|}
\hline $\begin{array}{l}\text { S } \\
1 .\end{array}$ & $\begin{array}{c}\text { Outpu } \\
\text { t } \\
\text { Param } \\
\text { eters }\end{array}$ & $\begin{array}{c}\text { Objec } \\
\text { tive }\end{array}$ & $\begin{array}{c}\mathrm{Sp} \\
\text { ee } \\
\mathrm{d} \\
\text { (v) } \\
\mathrm{m} / \\
\mathrm{mi} \\
\mathrm{n}\end{array}$ & $\begin{array}{c}\text { Fee } \\
\mathrm{d} \\
\text { (f) } \\
\mathrm{mm} \\
/ \mathrm{rev}\end{array}$ & $\begin{array}{l}\text { De } \\
\mathrm{pt} \\
\mathrm{h} \\
\text { of } \\
\mathrm{Cu} \\
\mathrm{t} \\
(\mathrm{m} \\
\mathrm{m})\end{array}$ & $\begin{array}{c}\text { Pred } \\
\text { icte } \\
\text { d } \\
\text { Res } \\
\text { ult }\end{array}$ & $\begin{array}{c}\text { Experi } \\
\text { menta } \\
1 \\
\text { Result }\end{array}$ & $\begin{array}{c}\mathrm{Er} \\
\text { ro } \\
\mathrm{r}\end{array}$ \\
\hline 1 & $\begin{array}{l}\text { Cuttin } \\
\text { g } \\
\text { Temp } \\
\text { eratur } \\
\text { e }\end{array}$ & $\begin{array}{c}\text { To } \\
\text { Mini } \\
\text { mize } \\
\text { Cuttin } \\
\text { g } \\
\text { Temp } \\
\text { eratur } \\
\text { e }\end{array}$ & 95 & $\begin{array}{l}0.0 \\
75\end{array}$ & $\begin{array}{l}0 . \\
5\end{array}$ & $\begin{array}{c}102 . \\
43\end{array}$ & 120 & $\begin{array}{l}14 \\
.6 \\
4\end{array}$ \\
\hline 2 & $\begin{array}{l}\text { Flank } \\
\text { Wear }\end{array}$ & $\begin{array}{c}\text { To } \\
\text { Mini } \\
\text { mize } \\
\text { Flank } \\
\text { Wear }\end{array}$ & 95 & $\begin{array}{l}0.0 \\
75\end{array}$ & $\begin{array}{l}0 . \\
5\end{array}$ & $\begin{array}{c}0.02 \\
5\end{array}$ & 0.027 & $\begin{array}{l}7 . \\
40\end{array}$ \\
\hline
\end{tabular}

\section{CONCLUSION}

1. It was found that the predicted results matched well with the experimental results.

2. In the present investigation revealed that cutting speed of $95 \mathrm{~m} / \mathrm{min}$, feed rate of $0.075 \mathrm{~mm} / \mathrm{rev}$ and depth of cut of $0.5 \mathrm{~mm}$ can bring forth better cutting performance.

3. Since no cutting fluid was used in the investigation it promoted green environment in the shop floor, minimized the industrial hazard.

\section{REFERENCES}

1. Mohammad Usman Ghani \& Nuri A. Abukhshim \& M A. Sheikh, An Investigation of Heat Partition and Tool Wear in Hard Turning of H13 Tool Steel with CBN Cutting Tools, International Journal of Advanced Manufacturing Technology (2008), Volume 39, pp.874888

2. Yong Huang \& Y. Kevin Chou \& Steven Y. Liang, CBN Tool Wear in Hard Turning: a Survey on Research Progresses, International Journal of Advanced Manufacturing Technology, (2007) Volume 35, pp. 443453.

3. Sanjeev Saini, Inderpreet Singh Ahuja, and Vishal S. Sharma, Influence of Cutting Parameters on Tool Wear and Surface Roughness in Hard Turning of AISI H1 1 Tool Steel using Ceramic Tools, International Journal of Precision Engineering and Manufacturing, Volume 13, Number 8, pp. 1295-1302

4. Viktor P. Astakhov, Effects of the Cutting Feed, Depth of Cut, and Workpiece(Bore) Diameter on the Tool Wear Rate, International Journal of Advanced Manufacturing Technology, (2007), Volume 34, pp. 631-640.

5. P. K. Philip, A. S. Varadarajan, B. Ramamoorthy, Influence of Cutting Fluid Composition and Delivery Variables on Performance in Hard Turning Using Minimal Fluid in Pulsed Jet Form, Journal of the Institution of Engineers (India), (2000), pp. 68-72.

6. R. H. Lochner, J.E. Matar, 'Designing for Quality, Chapman and Hall, London, pp.77-95. 